\title{
O RECADO DO MORRO: A ESTÓRIA DA EXPERIÊNCIA FORMATIVA DE PEDRO ORÓSIO ${ }^{1}$
}

\author{
RECADO DO MORRO: THE STORY OF PEDRO \\ ORÓSIO'S FORMATIVE EXPERIENCE
}

\begin{abstract}
RECADO DO MORRO: LA HISTORIA DE LA EXPERIENCIA FORMATIVA DE PEDRO ORÓSIO
\end{abstract}

\begin{abstract}
BRUno PUCCI ${ }^{1}$
Gloria Bonilha CaVaggioni ${ }^{1}$

Luis Fernando Altenfelder de Arruda Campos ${ }^{2}$

Universidade Metodista de Piracicaba (UNIMEP), Piracicaba/SP - Brasil ${ }^{1}$ Universidade Estadual Paulista "Júlio de Mesquita Filho"

(UNESP), Araraquara/SP - Brasil ${ }^{2}$
\end{abstract}

REsumo Este ensaio se propõe a interpretar o conto "Recado do Morro", de Guimarães Rosa, em diálogo com as reflexões estético-filosóficas de Theodor Adorno. O que nos dá base para o empreendimento é o fato de os contos de Guimarães Rosa apresentarem uma densidade semântica, possibilitando uma pluralidade de leituras. Nessa perspectiva, destacamos cinco eixos teórico-metodológicos para nos orientar nessa empreitada: a) a tensão entre a mimese e a racionalidade, entre o reino da natureza, da sensibilidade e as dimensões do construtivo e das técnicas; b) a constelação - recurso utilizado por Adorno para caracterizar, com mais proximidade, o objeto de conhecimento - como procedimento metodológico de Rosa na caracterização de seus personagens centrais; c) A obra de arte como crítica da sociedade de onde ela proveio; d) O Recado do Morro como uma "estória de formação" de seu protagonista. À medida que a estória da canção vai se formando, também o protagonista da estória vai constituindo sua identidade pessoal; e) A obra de arte como irrupção da objetividade na consciência subjetiva de Pedro Orósio.

Palavras-chave: Recado do Morro; Pedro Orósio; Experiência formativa; Guimarães Rosa; THEOdOR Adorno.

Guimarães Rosa utiliza o termo "estória” para nomear os seus contos. Ver o conto Aletria e Hermenêutica, de seu livro Tutaméia: Terceiras Estórias. Rio de Janeiro: José Olympio Editora, 1976. 
Abstract This essay proposes to interpret the short story "Recado do Morro", by Guimarães Rosa, in dialogue with the aesthetic-philosophical reflections of Theodor Adorno. What gives us the basis for the study is the fact that the short stories of Guimarães Rosa present a semantic density, enabling a plurality of readings. From this perspective, we highlight five theoretical-methodological lines to guide us in this endeavor: a) the tension between mimesis and rationality, between the realm of nature, sensitivity and the dimensions of the constructive and the technique; b) the constellation - a resource used by Adorno to characterize, with more proximity, the object of knowledge - as Rosa's methodological procedure in the characterization of the central characters; c) the work of art as a critique of the society from which it came; d) Recado do Morro as a "formation story" of its protagonist. As the story of the song is being formed, the protagonist of the story is also constituting his personal identity; e) The work of art as an outburst of objectivity in the subjective consciousness of Pedro Orósio.

Keywords: Recado do Morro; Pedro Orósio; Formative experience; Guimarães Rosa; THEODOR ADORNo.

Resumen El ensayo que sigue propone la interpretación del cuento O Recado do Morro, de Guimarães Rosa, en dialogo con las reflexiones estético filosófico del filósofo Theodor Adorno. Para este emprendimiento nos apoyamos en el hecho de que los cuentos de Guimarães Rosa presentan una densidad semántica, lo que posibilita una pluralidad de lecturas. En esta perspectiva, distinguimos cinco ejes teórico- metodológicos para orientarnos en esta empresa: a) la tensión entre la mimesis y la racionalidad, entre el reino de la naturaleza, de la sensibilidad y las dimensiones del constructivo y de las técnicas; b) la constelación - recurso utilizado por Adorno para caracterizar, de forma más próxima, el objetivo del conocimiento - como procedimiento metodológico de Rosa en la caracterización de sus personajes centrales; c) La obra de arte como critica a la sociedad de donde ella proviene; d) $\mathrm{O}$ Recado do Morro como una historia de formación de su protagonista. A la medida en que la historia de la canción se va formando, también el protagonista de la historia construye su identidad personal; e) La obra de arte como invasión de la objetividad en la consciencia subjetiva de Pedro Osorio.

Palabras clave: Recado do Morro; Pedro Orósio; Experiencia formativa; Guimarães Rosa; THEOdor Adorno.

\section{INTRODUÇÃo}

“... as obras de arte que se apresentam sem resíduo à reflexão e ao pensamento não são obras de arte” (ADORNO, 2011, p. 188).

Este ensaio se propõe a interpretar o conto "Recado do Morro", de João Guimarães Rosa (1908-1967), em diálogo com as reflexões estético-filosóficas de Theodor Adorno (1903-1969). A pergunta que não quer calar, assim me adverte: - Mas esse conto não foi

Comunicações $\mid$ Piracicaba $\mid$ v. $26 \mid$ n. $1 \mid$ p. 197-216 | jan.-abr. 2019 
já analisado e interpretado por destacados escritores, filósofos e literatos?! Tem ele ainda alguma nova mensagem a nos dizer?! De fato, "Recado do Morro" - uma das sete estórias de Corpo de Baile, ${ }^{2}$ publicado, em dois volumes, em 1956, dez anos após a edição de Sagarana -, recebeu leituras, análises e interpretações de inúmeros intelectuais brasileiros, entre os quais destacamos: o filósofo Bento Prado Junior; ${ }^{3}$ a escritora Ana Maria Machado; ${ }^{4}$ a tradutora e intérprete Susana Kampff Lages; ${ }^{5}$ o músico, compositor e ensaísta João Miguel Winisk. ${ }^{6}$ Mas, como diz Ana Maria Machado (2003), a obra de Guimarães Rosa apresenta uma pluralidade de leitura, é impossível pretender fixar num sentido único toda a densa flutuação semântica de um texto seu; e, como complementa Theodor Adorno (2011, p. 198), "as obras, sobretudo as de mais elevada dignidade, aguardam a sua interpretação". Ousamos, com o apoio do ensaísta, filósofo e esteta frankfurtiano, detectar, revelar alguns elementos do conteúdo de verdade desse conto, ainda não decifrados por seus comentadores.

E, para situar o leitor no contexto do conto, vamos buscar em uma missiva do próprio Guimarães Rosa ao padre João Batista Boaventura Leite o resumo da estória:

Um homem bom, forte, simples, primitivo, identificado com a natureza no que ela tem de mais alto, Pedro Orósio (Pedro: a pedra; "oros", em grego, monte) por apelido Chambergo (“chã”: planalto; "Berg”, em alemão: monte), não sabe que está correndo grave perigo: seus falsos companheiros maquinam assassiná-lo. Mas a própria natureza (que se confunde, aqui, com o subconsciente de Pedro, se não com o "subconsciente coletivo" ou com o fundo escuro extra-racional, do qual as revelações brotam) tenta avisá-lo do perigo. O Morrão, Morro da Garça. Pedro, ele mesmo, nada escuta, nada capta; porque está voltado demais para a aparente realidade, para o mundo social, externo, de relação, objetivado - sempre enganoso. Quem apreende o recado, inicialmente, é o troglodita e estrambótico Gorgulho. E, no seguir dos dias, o "recado" do Morro vai sendo retransmitido, passado de um a outro ser receptivo - um imbecil (o Qualhacôco), um menino (o Joãozezim), um bôbo de fazenda (o Guégue). Um louco (o Nominedômine), outro dôido (o Coletor), até chegar a um artista, poeta, compositor (o Pulgapé). Sete elos, 7, número simbólico, como simbólicos são os nomes das fazendas e fazendeiros percorridos pela comitiva. Cada um daqueles 7, involuntariamente, vai enriquecendo e completando o recado, enquanto que aparentemente o deturpam. De cada vez que a retransmissão se faz, o Pedro está presente e nada entende. Só dão importância àquilo os "pobres de espírito", marginais da razão comum,

2 Neste artigo seguimos a Edição Comemorativa 50 Anos (1956-2006) de Corpo de Baile, publicada pela Editora Nova Fronteira, em dois volumes: o primeiro abriga os romances: "Campo Geral"; "A estória de Lélio e Lina"; "Dão-Lalalão"; "Buriti”. O segundo volume acolhe os contos: "Uma estória de Amor"; "O recado do Morro"; e "Cara-de-Bronze".

3 "O Destino Decifrado - Linguagem e Existência em Guimarães Rosa" (ensaio). In: Alguns Ensaios: Filosofia, Literatura, Psicanálise. São Paulo: Paz e Terra, 2. ed. 2000.

4 “Em Nome do Homem”, 2003 (capítulo de livro). In: Recado do Nome: Leitura de Guimarães Rosa à luz do nome de seus personagens. Rio de Janeiro: Editora Nova Fronteira, 3. ed. 2003.

5 "Descaminhos da leitura como escrita e tradução: uma interpretação de "O recado do morro", de João Guimarães Rosa”, 2014 (artigo). In: Cadernos de Tradução, ISSN 2175-7968, Florianópolis, Brasil.

6 "O recado do morro [João Guimarães Rosa]" (vídeo). Disponível em: https://www.youtube.com/watch?$\mathrm{v}=\mathrm{BE} 64 \mathrm{BrBt52E}$. Acesso em 14 de mar. 2017. 
entes inofensivos, simples criaturas de Deus. E, enfim, o artista, que, movido por intuição mais acesa, captura a informe e esdrúxula mensagem sob a forma de inspiração poética, ordenando-a em arte e restituindo-lhe o oculto sentido: tudo serviu como gênese de uma canção. Então, só então, sim, ouvindo essa canção, e, principalmente, repetindo-a, cantando-a (isto é, perfilhando-a no coração, na alma) é que Pedro entende o importante e vital significado da mesma. Recebe o aviso, fica repentinamente alertado, desperta, e reage contra os traiçoeiros camaradas, no último momento. ${ }^{7}$

Um aspecto importante não foi ressaltado por Rosa no resumo do conto: o enxadeiro Pedro Orósio é o guia de um grupo de viajantes, formado por um naturalista estrangeiro, seo Alquiste, por um sacerdote em período de férias, frei Sinfrão e por um fazendeiro, seo Jujuba, interessado em ampliar seu rebanho de gado. Por sua vez, na longa caminhada, Pedro Orósio é auxiliado por Ivo, também morador do mesmo arraial, um vizinho seu. A viagem, que dura cerca de um mês, parte de Cordisburgo, cidade natal de Rosa, passa pela região de Curvelo, onde se encontra o Morro da Garça, e segue em direção aos Gerais, ao norte de Minas, para além do rio São Francisco. Outro detalhe que merece ser destacado no resumo é o motivo que está impulsionando os falsos companheiros a arquitetarem a morte de Pedro Orósio:

Que o Pedro era ainda teimoso solteiro, e o maior bandoleiro namorador: as moças todas mais gostavam dele do que de qualquer outro; por abuso disso, vivia tirando as namoradas, atravessava e tomava a que bem quisesse, só por divertimento de indecisão. Tal modo que muitos homens e rapazes lhe tinham ódio, queriam o fim dele, se não se atreviam a pegá-lo era por sensatez de medo, por ele ser turuna e primão em força, feito um touro ou uma montanha (ROSA, 2006, p. 394).

É pertinente observar que Rosa, nessa missiva ao padre redentorista, quando solicitado a falar sobre o referido conto, deixa claro que, como seu autor, não tem o direito de "explicar" uma estória sua já publicada. De fato, o conto, quando vem à luz, ganha vida e substância própria, autonomiza-se de seu "criador"; torna-se um ser histórico. E nem sempre o seu conteúdo de verdade reflete a intencionalidade do artista. Adorno, no final de sua primeira aula sobre Estética, em novembro de 1958, na Universidade de Frankfurt, ratifica enfaticamente o posicionamento do mineiro de Cordisburgo:

La obra de arte se vuelve algo objetivo precisamente en la medida en que se enfrenta al artista como algo autónomo y organizado en sí mismo. Y casi diría: cuanto más plenamente lo consiga, cuanto menos sea la obra de arte sólo documentación del artista, cuanto más sea ella una cosa que habla por sí misma, tanto más alto figurará también en general (2003, p. 65).

7 Carta de Guimarães Rosa dirigida ao padre João Batista Boaventura Leite, em 26 de agosto de 1963. In: http://orecadodomorrodeguimaraesrosa.blogspot.com.br/2008/08/carta.html. Acesso em: 14/03/2017. 
O resumo do conto apresentado por Rosa (1963) se fundamenta antes nas observações de seus leitores críticos. É o que afirma na missiva: "Só posso achar que não estarão talvez de todo errados os comentadores (...) que viram naquela noveleta, principalmente, a afirmação do primado da intuição, da inspiração sobre as operações e conceituações da lógica (...)". Sobre a predominância do sensitivo ao cognitivo em suas novelas e romances, Rosa já tinha anotado essa peculiaridade em carta a seu tradutor italiano Edoardo Bizzari: "Você já notou, decerto, que, como eu, os meus livros, em essência, são 'anti-intelectualistas' defendem o altíssimo primado da intuição, da revelação, da inspiração, sobre o bruxolear presunçoso da inteligência reflexiva, da razão, a megera cartesiana" (ROSA, 2003, p. 57).

Essa observação pontual de Rosa, sobre o primado da intuição a respeito da inteligência reflexiva em seus textos e contextos, de um lado, vem de encontro à tensão entre a mimese e a racionalidade presente na obra de arte; de outro lado, não enfraquece a importância destacada das técnicas na construção desse novo ser vivo. A mimese, o momento da irracionalidade, da natureza, da vida, do somático, dos sentidos, da intuição, é uma constante na composição das quase 80 páginas do conto roseano. Destacamos algumas de suas manifestações: o Morro que emite um recado: "Lá - estava o Morro da Garça: solitário, escaleno e escuro, feito uma pirâmide. ... testemunho. Belo como uma palavra" (ROSA, 2006, p. 401; 404); a intensa e extensa descrição/pintura das coisas da natureza: as lapas, os rochedos, os animais, as aves, as flores (IDEM, p. 391-393); "as estrelas de Cordisburgo - o seo Olquiste falou - eram as que brilhavam, talvez no mundo todo, com mais agarre de alegria” (IDEM, p. 397); “... a Gruta de Maquiné - tão inesperada de grande, com seus sete salões encobertos, diversos, seus enfeites de tantas cores e tantos formatos de sonho, rebrilhados risos de luz...” (IDEM, p. 397); “...os buritis saudando, levantantes, sempre tinham estado lá, em sinal e céu, porque o buriti é mais vivente” (IDEM, p. 398); o predomínio da irracionalidade, da sensibilidade, no personagem que ouve o recado do Morro e nos que o transmitem, com seus acréscimos e idiossincrasias; o transtorno corporal como momento ímpar de inspiração de Laudelim, ao ouvir o relato do Coletor, o penúltimo transmissor da mensagem do Morro; o som da cantiga de Laudelim e a captação somática da canção como momento de catarse e de salvação de Pedro Orósio. Enfim, os elementos e momentos miméticos, como resíduos irracionais, se imiscuem na construção da obra de arte e lhe dão vida, movimento e mistério. "A arte é refúgio do comportamento mimético"; "A mimese é na arte o pré-espiritual, o contrário do espírito e, por outro lado, aquilo a partir do qual ele se incendeia" (ADORNO, 2011, p. 88; 184).

O outro momento/elemento da obra de arte, que se contrapõe e se compõe com o mimético, é o da racionalidade:

A arte é racionalidade, que critica esta sem se lhe subtrair; não é algo de pré-racional ou irracional, como se tivesse antecipadamente condenado à inverdade perante o entrelaçamento de qualquer atividade humana na totalidade social. ... A racionalidade é, na obra de arte, o momento criador de unidade e organizador, não sem relação com a que impera no exterior, mas não copia a sua ordem categorial (ADORNO, 2011, p. 90-91). 
A racionalidade na obra de arte é resultado da construção, da intensidade do pensar e do agir, do indagar, do relacionar as partes entre si e com o todo na busca de sua forma, da utilização e aplicação das técnicas intraestéticas na composição do artefato, desse novo ser vivo. Nessa perspectiva, observamos como Rosa, amante da intuição, da mimese, da irracionalidade, utiliza, com a mesma vontade de potência, os momentos/elementos racionais na construção de sua obra de arte. Poderíamos mostrar aqui e agora um número infindo de técnicas construídas e empregadas por ele na confecção do "Recado do Morro". Técnicas essas que se expressam por meio da construção de palavras e expressões - neologismos -, que articulam e tensionam a fala do homem do sertão com a ortodoxia das expressões linguísticas; técnicas que relacionam os fenômenos da natureza e da vida do homem rural com os mitos provindos de povos antigos, de civilizações ancestrais, em que os deuses e os astros eram tidos como pontos de referências e de orientações cósmicas e religiosas para a vida humana contra os constantes perigos que ameaçavam o sobreviver. Vamos destacar apenas duas técnicas que nos chamaram a atenção e que nos são relatadas pelo próprio Guimarães Rosa.

A primeira diz respeito à caracterização de Gorgulho, cujo nome de verdade era Malaquias, o que ouviu por primeiro o recado do Morro: "Um velhote grimo, esquisito, que morava sozinho dentro de uma lapa, entre barrancos e grotas - uma urubuquara - casa dos urubus, uns lugares com pedreiras" (ROSA, 2006, p. 399). Bizzarri, seu tradutor para o italiano, o consulta sobre o significado do adjetivo "grimo", atribuído ao Gorgulho: "um velhote grimo". Rosa assim lhe responde:

\begin{abstract}
"Grimo": de uma feiúra sério-cômica, parecendo com as figuras dos velhos livros de estórias; feio carateante; de rosto engelhado, rugoso. (Cf. em italiano: grimoso $=$ Vecchio grinzoso.) Em inglês: grim = carrancudo, severo, feio, horrendo, sombrio etc. Em alemão: Grimm = furioso, sanhoso. Em dinamarquês: grimme $=$ feio. Em português: grima $=$ raiva, ódio; grimaça $=$ careta". "Eu quis captar o quid, universal, desse radical" (ROSA, 2003, p. 69). ${ }^{8}$
\end{abstract}

Esse zelo de Rosa no nomear a coisa, no tentar dizer o que ela é, no buscar aproximar intimamente o objeto de seu conceito, a coisa de seu termo, aspirando a identificação entre ambos, para expressar aquilo que ainda não foi dito, o caracteriza, certamente, como um literato ímpar. ${ }^{9}$ E ele age dessa maneira, porque seu ofício de escritor, de forma imanente, exige dele essa postura; e também porque seu escrito, como obra de arte, só conseguirá

8 "Falo: português, alemão, francês, inglês, espanhol, italiano, esperanto, um pouco de russo; leio: sueco, holandês, latim e grego (mas com o dicionário agarrado); entendo alguns dialetos alemães; estudei a gramática: do húngaro, do árabe, do sânscrito, do lituânio, do polonês, do tupi, do hebraico, do japonês, do checo, do finlandês, do dinamarquês; bisbilhotei um pouco a respeito de outras. Mas tudo mal. E acho que estudar o espírito e o mecanismo de outras línguas ajuda muito à compreensão mais profunda do idioma nacional. Principalmente, porém, estudando-se por divertimento, gosto e distração". (Trecho de carta-entrevista para sua prima Lenice Guimarães de Paula Pitanguy.) In: http://www.elfikurten.com.br/2013/05/joao-guimaraes-rosa-o-demiurgo-do-sertao.html. Acesso: 16/03/2017.

9 Cf. PUCCI, Bruno. Para Rosa com Adorno: a luta agônica da palavra e do conceito em busca do "quem" das coisas. In: Artefilosofia (UFOP), v. 8, p. 122-133, 2010. 
sobreviver, se direcionar todo seu esforço construtivo nessa direção. Eis o que ele diz, em entrevista, a Harriet de Onís, tradutora de suas obras para o inglês:

\begin{abstract}
A meu ver, o texto literário precisa ter gosto, sabor próprio - como na boa poesia. O leitor deve receber sempre uma pequena sensação de surpresa - isto é, de vida (...). Acho também que as palavras devem fornecer mais do que significam. As palavras devem funcionar também por sua forma gráfica, sugestiva e sua sonoridade, contribuindo para criar uma espécie de 'música subjacente' (ROSA apud Reinaldo, 2005, p. 24).
\end{abstract}

A segunda técnica a ser destacada é-nos anunciada também por Rosa, espontaneamente, em correspondência com seu tradutor italiano. Diz ele: "Agora, ainda quanto a 'O Recado do Morro', gostaria de apontar a Você um certo aspecto planetário ou de correspondências astrológicas, que valeria a pena ser acentuadamente preservado, talvez. Ocorre nos nomes próprios, assinalamento onomástico-toponímico". E relaciona: as 6 fazendas visitadas na excursão pelos personagens-viajantes, com seis planetas e com os seis companheiros de Pedro Orósio, que se articulam para matá-lo. Pela ordem: 1 - Jove... Júpiter... o Jovelino; 2 - dona Vininha... Vênus... o Veneriano; 3 - Nhô Hermes... Mercúrio... o Zé Azougue; ${ }^{10} 4$ - Nhá Selena... Lua... o João Lualino; 5 - Marciano... Marte... o Martinho; 6 - Apolinário... Sol... o Hélio Dias ${ }^{11}$ (ROSA, 2003, p. 86).

No resumo do conto elaborado por Rosa, como vimos, ele faz menção do cabalístico número 7: "Sete elos, 7, número simbólico, como simbólicos são os nomes das fazendas e fazendeiros percorridos pela comitiva. Cada um daqueles 7 , involuntariamente, vai enriquecendo e completando o recado, enquanto que aparentemente o deturpam" (ROSA, 1963). Faltaria, pois, na relação citada, o nome de um fazendeiro, de um planeta e de um falso companheiro de Pedro Orósio; esses nomes, igualmente, aparecem em outro momento do texto, na mesma relação anteriormente estabelecida: 7 - Fazenda de seo Joca Saturnino (local da festa organizada pelos falsos companheiros para assassinarem Pedro Orósio)... Saturno... Ivo Crônico (cronos, o tempo, saturno). ${ }^{12}$ No texto de Rosa, a expressão utilizada por ele, na caracterização do número 7 é inusual = "um mais seis". "Um mais seis" eram os transmissores do recado - no caso, o "um" seria o Laudelim, que dá forma poético-musical ao recado; "um mais seis" eram os nomes dos donos das fazendas - o "um" se refere à fazenda aonde ia se dar o crime; "um mais seis" são os falsos companheiros de Pedro Orósio - o "um" se refere ao Ivo, o articulador do golpe. "Um mais seis" eram os dias da semana; o "um" é o dia do Sol, Sunday, em inglês; e Sunntag, em alemão, dia em que iria acontecer a festa do Rosário, na aldeia.

Na expressão de Susana Lages (2014, p. 215-216),

10 Na mitologia romana, Mercúrio (associado ao deus grego Hermes) é um mensageiro e deus da venda, lucro e comércio. Azougue = Mercúrio [Química] Designação comum atribuída ao mercúrio, elemento químico.

11 Na mitologia grega, Hélio era a representação divina do Sol em todas as suas fases e latitudes, desde o nascer ao desaparecimento.

$12 \mathrm{O}$ autor omite a última, sétima correspondência: Cronos/Saturno, o Tempo que está por toda a parte - Ivo Crônico. 
Ao atrair contra si o ódio produzido pelos ciúmes dos companheiros Jovelino, Veneriano, Zé Azougue, João Lualino, Martinho, Hélio Dias, e também de Ivo Crônico, o personagem que o acompanha durante toda a viagem, Pedro Orósio atrai para si a fúria dos deuses: Júpiter, Vênus, Mercúrio/Hermes, Selene, Marte, Sol e finalmente a destruidora fúria saturnina de Cronos.

Apresentamos apenas alguns elementos miméticos e racionais utilizados por Rosa na composição de seu conto-poema, para destacar o papel central que eles - o imponderável e o refletido, o voluntário e o inconsciente - ocupam nesse processo dialético de o artista dar forma estética a um conteúdo específico, de o artista ser o braço estendido da obra de arte em sua vinda ao mundo como um ser vivo, que contém em si os resquícios e as contradições do espaço e do tempo de onde provém. Para Adorno, "a sobrevivência da mimese, a afinidade não-conceitual do produto subjetivo com o seu outro, com o não-estabelecido, define a arte como uma forma de conhecimento, e, sob esse aspecto, como também racional" (2011, p. 89). Apesar de, habitualmente, se reservar o processo de conhecimento à faculdade racional, intelectual, sem os momentos da sensibilidade, do imaginativo, da intuição, nossos conceitos seriam frios, inexpressivos, abstratos, desprovidos da dor e do sofrimento, que constituem a realidade do conhecido. Nessa perspectiva, a obra de arte, como expressão do mimético e do racional, se torna uma forma privilegiada de conhecimento do mundo e dos homens. Para Adorno,

“...experimentar el arte significa tanto como conocerlo"; ...y el conocimiento se refiere al conocimiento inmanente de la cosa misma, el hecho de que ustedes se entreguen por completo a esas síntesis que están prefiguradas, de algún modo, por las relaciones de los momentos sensibles particulares de la obra de arte y las realicen en forma pasiva-activa (2013, p. 489-491).

O frankfurtiano, em seu livro Dialética Negativa (2009), ciente dos percalços do conceito na tentativa de captar a concretude histórica de seu objeto, se serve de um procedimento teórico-metodológico criativo: a constelação. Para ele, quando os conceitos se articulam em forma de uma configuração estelar em torno do objeto que pretendem iluminar, eles alcançam, por meio desses relances, aquilo que o próprio conceito, abstrato, extirpou de si. E se utiliza de uma comparação dialética para representar visivelmente a imagem e a ideia desse procedimento:

Enquanto constelação, o pensamento teórico circunscreve o conceito que ele gostaria de abrir, esperando que ele salte, mais ou menos como os cadeados de cofres-fortes bem guardados; não apenas por meio de uma única chave ou de um único número, mas de uma combinação numérica (2009, p. 141-142).

Adorno, em seus escritos ensaístas, articula a ideia de construir uma constelação específica e concreta a partir dos elementos que o fenômeno observado lhe indica, de forma que a realidade sócio-histórica, que constitui seu conteúdo de verdade, se torne física e paulatinamente visível, palpável (Cf. PUCCI, 2012, p. 8).

Comunicações $\mid$ Piracicaba $\mid$ v. $26 \mid$ n. $1 \mid$ p. 197-216 | jan.-abr. 2019 
Percebemos uma semelhança acentuada de Rosa com Adorno no emprego desse procedimento metodológico no decorrer do conto "O Recado do Morro". Adorno, filósofo, trabalha com conceitos, pois são eles o instrumento que o pensador tem em mente para expressar suas ideias e desenvolver sua argumentação; a constelação, no caso é formada por um conjunto de conceitos que se tensionam entre si e se configuram em novos esclarecimentos. Rosa, literato, trabalha com palavras, pois são elas, enquanto expressões de ideias e de intuições, que dão vida e roupagem nova às suas estórias. As constelações, em seu texto, assumem formas específicas e complementares; elas configuram: a origem filológica da palavra ou do nome do ser, da paisagem descritos; expressões denotativas que o circunscrevem em seu estar-no-mundo, entre os semelhantes; as metáforas e comparações que o delimitam e, ao mesmo tempo, o potencializam. Queremos tomar como objeto de observação do recurso da constelação a caracterização de dois personagens centrais do conto em análise: Pedro Orósio e do Nominedômine. Quais são os elementos - palavras, expressões, comparações, - que se articulam entre si, em diversos momentos do texto para dizer, de forma a mais verídica possível, o que são esses dois personagens, qual é a imagem que os leitores atentos constroem de cada um deles.

Vamos começar pelo Pedro Orósio, o guia da viagem. Rosa se serve de diferentes recursos linguísticos e figurativos para ressaltar a constituição física e o caráter desse personagem. Destacamos alguns desses recursos constelatórios:

- A adoção da "linguagem adâmica"13 na caracterização do nome e dos apelidos do personagem: Pedro = a pedra; Orósio = "oros", em grego, monte, montanha; "osio" = escolhido. Apelidos: 1 - Pedrão Chãbergo. Pedrão = grande pedra ou montanha; chã = chão, planície; Berg = pedra, no alemão; Berger = pastor, vaqueiro, no francês; 2 - Pê-Boi e mesmo Pêboizão = sua ligação com o gado e com a terra; seu tamanho, seu pé descalço (Cf. MACHADO, 2003, p. 114-115). Na afirmação de Lages (2004, p. 217), “a identidade em formação de Pedro Orósio não corresponde a uma individualidade univocamente constituída: se desdobra em várias identidades provisórias".

- A descrição de Pedro Orósio feita pelo narrador: 1 - logo no início da novela: "Pedro Orósio: moço, a nuca bem feita, graúda membradura; e marcadamente erguido: nem lhe faltavam cinco centrímetros para ter um talhe de gigante. ... capaz de ... levantar do chão um jumento arreado, carregando-o nos braços por meio quilômetro..." (ROSA, 2006, p. 389); 2 - Pedro Orósio, respondendo às perguntas de frei Sinfrão, atendendo à curiosidade de seo Alquiste: "— Quer saber donde você é, Pedrão ..."; “- - Se você é solteiro ou casado, Pedro?”; “- E quando você toma juízo e se casa?” (IDEM, p. 394-5); 3 - O Julgamento das pessoas do arraial: “...apreciavam o Pedro - principalmente por seu tamanho em desabuso, forçudo assim, dava gosto e respeito" (IDEM, p. 445).

13 "Linguagem adâmica" é aquela em que há uma convergência, como que absoluta, entre o nome e a coisa; em que há o ideal expressivo de dizer as coisas mesmas, chamá-las pelo nome, que diz o que a coisa é; se contrapõe à linguagem instrumentalizada da comunicação. "Porque Deus criou as coisas, a palavra criadora nelas contida é o germe do nome cognoscível (BENJAMIN, apud PERIUS), Oneide. "A filosofia da linguagem em Walter Benjamin" (2011). 
- Os constantes desejos de Pedro Orósio de voltar para os Gerais de onde tinha vindo; a tensão e os ciúmes dos companheiros, bem como, a vida difícil que levava, lhe trazia esses "imaginamentos", que se acham espalhados por todo o conto e que surgem em momentos de tensão, como no caso:

E nesses comenos, Pedro Orósio entrava repentino num imaginamento: uma
vontade de, voltando em seus Gerais, pisado o de lá, ficar permanecente, para os
anos dos dias. Arranjava uns alqueires de mato, roçava, plantava o bonito arroz,
um feijãozinho. Se casava com uma moça boa, geralista pelo também, nunca
mais vinha embora [...] Era uma vontade empurrada ligeiro, uma saudade a ser
cumprida. Mas pouco durou seu dar de asas, porque a cabeça não sustentou
demora, se distraiu, coração ficou batendo somente (ROSA, 2006, p. 409).

Segundo Lages (2004, p. 219), a atitude reflexiva do protagonista se manifesta como "imaginamento", como uma mistura de imaginação com pensamento, como um "dar de asas", uma espécie de escapadela das atribulações da vida quotidiana. ... "uma saudade a ser cumprida".

As metáforas criadas pelo seo Aquiste, o naturalista estrangeiro, para descrever Pedro Orósio: 1 - nas primeiras páginas do conto: "Seu Alquiste quis bater uma fotografia de Pedro Orósio: recomendou que ele ficasse teso, descidos os braços. - "Grande... Muito grande..." - falou. - "Bom para soldado!" (IDEM, p. 385); 2 - "Eles seguiam Pedro Orósio; era vaqueão, nele se fiavam. Ia bem na dianteira. Aquele elevado moço, sem paletó, a camisa furada, um ombro saindo por um buraco; ... e à cintura a garrucha na capa, e um facão; ia, a longo. - "Sansão..." - disse seo Alquiste" (IDEM, p. 399); 3 - Ao final do conto, quando o Laudelim está apresentando a cantiga do Rei:

E, nesse ardor, senhor Alquist limpava os óculos, e, tornando a entrar na sala o pobre do Pedrão Chãbergo, um capiau simplório, assim transvisto, sem outro destaque a não ser o da estatura - o senhor Alquist o admirava, dizia: Kalós Kágathós. O sertão tivesse mais um assim (ROSA, 2006, p. 461).

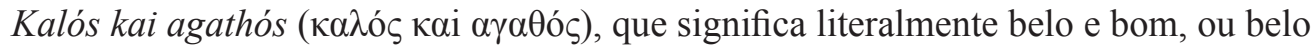
e virtuoso. O adjetivo kalós compreendia os conceitos de bondade, nobreza e beleza, e podia ser usado na descrição de seres animados ou inanimados. Agathós era usado sem conotações físicas ou estéticas, mas descrevia a ética ou a bravura de uma pessoa. kalós kai agathós, um ideal de conduta pessoal; uma formação espiritual plenamente consciente (Cf. JAEGER, 2001, p. 23-36).

Ou seja, o personagem principal do Recado do Morro é construído por Guimarães Rosa por meio de um processo constelatório, em que inúmeras técnicas estéticas entram em ação para nomear dimensões específicas e constitutivas de sua pessoa e de sua personalidade: a linguagem adâmica, em que seu nome e alcunhas tendem a identificar-se com o que nomeiam; as descrições expressas pelo narrador, em diversos momentos do texto, que

Comunicações $\mid$ Piracicaba | v. $26 \mid$ n. $1 \mid$ p. 197-216 | jan.-abr. 2019 
ressaltam aspectos relacionados a seu porte físico e corporal, a seu modo de viver, às terras de onde ele provém; as manifestações da interioridade do personagem que oscila, nos voos de seu pensamento, entre o regressar às terras de origem ou permanecer no espaço geográfico e temporal em que se encontra no momento; as metáforas que colocam em destaque e admiração a força de seu complexo físico, mas também, e sobretudo, a força, a beleza e a nobreza de seu caráter. O conceito, a palavra, a admiração, a poesia, a música, a pintura, a escultura se harmonizam e se tensionam entre si na descrição e na constituição desse personagem, para o qual até o Morro envia um recado de urgência.

Mas, há outro personagem do conto para o qual Guimarães Rosa dedica mais espaço e importância e adota o procedimento constelatório para melhor caracterizá-lo. Trata-se do quinto receptor da mensagem, o Nomindome, tido como doido varrido, e que, segundo um velho morador do local "tinha passado bons anos no Seminário de Diamantina". Ninguém conhecia seu verdadeiro nome. Só era conhecido pelo apelativo de Jubileu ou Santos Óleos. Já fazia uns dez anos que ele sobrevivia na região, indo de lá prá cá, "pronunciando brados do fim-do-mundo" no estreito prazo de três anos (Cf. ROSA, 2006, p. 433). De fato, quando o Guégue (o quarto receptor do recado do Morro) e Pedro Orósio se dão de frente com ele, sua saudação é a seguinte: “- Bendito! Que evém em nome em d'homem..." (IDEM, p. 428). Na verdade, a expressão correta é: Bendito o que vem em nome do Senhor! E sua expressão latina correspondente: Benedictus qui venit in nomine Domini. E as variações do nome que a estória utiliza para se dirigir a ele vão acontecendo conforme o andamento do próprio texto: Nomindome, quando é nomeado pela primeira vez (p. 433); Nominedômine, quando Pedro Orósio o encontra, aos gritos, no sábado de manhã, véspera da festa do Rosário, na cidade (p. 438); e Nomendomen, quando Pedro Orósio toma consciência da traição dos sete falsos companheiros, avança sobre eles e grita: "—-Toma, cão! Viva o Nomendomen" (p. 467). Esse personagem vai causar um transtorno enorme no lugarejo, pois entra no interior da igreja, sobe até o campanário, toca prolongadamente os sinos e quando a igreja está cheia de curiosos, começa a fazer a pregação sobre o fim do mundo e só termina quando os freis chegam e se dirigem até ele. No contexto de sua pregação, faz a revelação do recado do Morro, a partir da versão que tinha recebido do Guégue e com alguns pequenos acréscimos. Pedro Orósio está presente na pregação do Nominedômine, mas sua preocupação, no momento, é proteger os freis e outras pessoas de possível agressão do pregador!

No caso, o procedimento constelatório, utilizado por Rosa, caracteriza com pertinência sua dimensão religiosa, como o receptor e divulgador da mensagem do Morro, que mescla esse anúncio a uma conotação apocalíptica e de urgência, e, mesmo assim, Pedro Orósio, no momento, não vai captá-la. Só ao final, antes de atacar seus malfeitores, se deixou tomar pela mensagem e fez um agradecimento público ao Nomendomem. Este recebeu, em seu percurso no conto, como vimos, vários apelativos relacionados à religião católica, pelo teor de sua pregação. O termo Nominedômine é extraído de um hino da missa, que intercala fragmentos de dois livros históricos, o Antigo e o Novo Testamento: a profecia de Isaías sobre a vinda do Messias e o evangelho quando narra a entrada de Jesus em Jeru- 
salém, pouco antes de seu julgamento. Diz o hino: "Santo, Santo, Santo, Senhor Deus do universo/ O Céu e a Terra proclamam a Vossa glória/ Hosana nas alturas! Bendito o que vem em nome do Senhor/ Hosana nas alturas!". Por sua vez, esse personagem tinha mais dois apelidos vinculados à sua missão: Jubileu e Santos Óleos. O Jubileu, para os católicos, refere-se à indulgência plenária concedida pelo papa a cada 25 anos, como remissão das penas temporais cabíveis para pecados cometidos, depois de os mesmos terem sido perdoados. ${ }^{14}$ Santos Óleos se referem aos óleos que são bentos na quinta-feira da Semana Santa e com os quais se untam os fiéis em alguns sacramentos: no batismo, a cabeça; na confirmação, a testa; na extrema-unção, as partes do corpo relacionadas com os cinco sentidos e ligadas ao pecado..$^{15} \mathrm{O}$ Nomendômine fazia, pois, jus a esses apelativos: "Às almas, meus irmãos! O fim do mundo, mesmo, já começou. ...E vem vindo... Olha os prazos! Vamos rezar, vamos esquentar, vamos ser! Bons jejuns ... Alerta - às almas" (ROSA, 2006, p. 441). E, em determinado momento de sua pregação, ele retoma uma expressão latina da liturgia católica tão cara aos seus fiéis: "Orate frates ..."; é quando o sacerdote, que reza a missa, se volta aos presentes e os convida a rezar: "Orai irmãos" (IDEM, p. 441).

Essa pluralidade onomástica de quem é chamado Jubileu, Santos Óleos, Nominedomine, Nomindome, Nomendomen, que em seu discurso fala em Cá traz, Caifaz e Malaquias (mensageiro de Deus), marca o momento mais delirante da linguagem do recado (MACHADO, 2003, p. 102).

Guimarães, ao construir esse personagem, por um lado apresenta com detalhes e propriedade a presença e a influência da religião católica nas comunidades rurais mineiras do início da segunda metade do século XX; ao mesmo tempo, deixa transparecer sua vinculação espiritual com setores da igreja católica, que tiveram presença marcante em sua formação educativa e cultural quando criança, em Cordisburgo, e como estudante do curso ginasial e colegial, em Belo Horizonte, no Colégio Arnaldo, de padres alemães. Na carta endereçada ao padre João Batista, diz guardar "recordação viva e profunda admiração" pelos missionários redentoristas de Belo Horizonte e de Curvelo; e se lembra do tempo que ajudava missa e comia manga e nêsperas na Chácara dos padres" (1963). Por outro lado, as principais cerimônias religiosas no tempo de Rosa, por exemplo, a missa dominical, eram celebradas na língua latina.

Retomemos a análise do conto e vamos caminhando com os personagens da comitiva na tentativa de decifrar os segredos do morro nos gestos e nas palavras de seus transmissores.

"A priori, antes de suas obras, a arte é uma crítica da feroz seriedade que a realidade impõe sobre os seres humanos. Ao dar nome a esse estado de coisas, a arte acredita que está soltando amarras" (ADORNO, 2001, p. 13). Como vimos no conto, há uma pormenorizada e expressiva descrição da natureza: das lapas, rochedos, montes, animais, aves, árvores, flores; mas surge também, com destaque e continuidade, as manifestações de pobreza, de miséria, que assolam a sofrida vida dos moradores das fazendas e do sertão dos gerais.

${ }^{4}$ Cf. HOUAISS, A. Dicionário Houais da Língua Portuguesa, 2001, p. 1.688 e 1.608.

15 Santos Óleos. Significados In: https://www.google.com.br/search?q=santos+óleos+significado\&sa. Consulta: $13 / 03 / 2017$. 
"Mas que seria a arte enquanto historiografia, pergunta Adorno, se ela se desembaraçasse da memória do sofrimento acumulado?" (2011, p. 392). Observemos de perto a condição social dos receptores da mensagem do Morro: Gorgulho, nem casa tinha; morava sozinho dentro de uma gruta, em uma urubuquara - casa de urubus; entre buracos e grotas, há mais de trinta anos; plantava sua roça, colhia; cultivava seu de comer (ROSA, 2006, p. 399-405); Zaquias ou Catraz ou Qualhacôco, o segundo receptor do recado, irmão de Gorgulho, também morava em uma lapinha. A respeito deles frei Sinfrão comentou que Gorgulho ia "ver o outro espelêu, em sua outra espelunca ..." (IDEM, p. 412). Eis como o narrador apresenta Zaquias:

\begin{abstract}
Desde isso, porém, veio chegando, saco bem mal-cheio às costas e roupinha brim amarelo de paletó e calça, um camarada muito comprido, magrelo, com cara de sandeu - custoso mesmo se acertar alguma ideia de donde, que calcanhar-do-judas, um sujeito sambanga assim pudesse ter sido produzido. O paletó era tão grande que não se acabava, abotoados tantos botões, mas a calça chegava só, estreitinha, pela meia-canela (IDEM, p. 418).
\end{abstract}

Guégue, o quarto receptor do recado, "era o bobo da Fazenda de dona Vininha e seu Nhôto"; tratava dos porcos de ceva, levava a comida dos camaradas da roça, e cuidava de todo o serviço de terreiro; era o portador de bilhetes de dona Vininha para sua filha, que morava em outra fazenda (IDEM, p. 423); E o agitado Nominedômine? "Era um homem grenhudo, magro de morte .... Deitado debaixo de uma paineira, espojado em cima do esterco velho vacum, ele estava proposto de nu - só tapado nas partes, com um pano de tanga" (IDEM, p. 429).

Os receptores e transmissores do recado são muito pobres, não possuem quase nada, nem moradia nem vínculos familiares. Quase todos são seres marginais à sociedade; relacionam-se mais intensamente com a natureza.

Mas a arte não é social apenas mediante o modo da sua produção, (...), nem
pela origem social do seu conteúdo temático. Torna-se antes social através da
posição antagonista que adota perante a sociedade (...). Critica a sociedade pela
sua própria existência (ADORNO, 2011, p. 340$)$.

É sintomática, em determinado momento do conto, a reação de Pedro Orósio diante da realidade social que ele contempla, deprimido, na longa viagem pelo sertão. Já tinham passado o rio São Francisco, a fazenda do Apolinário, na vertente do rio Formoso e atingido os campos-gerais, para onde o protagonista, saudoso, almejava um dia voltar e lá viver. Mas o que ele mais via "era a pobreza de muitos, tanta míngua, tantos trabalhos e dificuldades. Até lhe deu certa vontade de não ver, de sair dali sem tardança" (ROSA 2006, p. 416).

E mesmo o grande acontecimento, que, no final do conto, movimentava o arraial onde Pedro Orósio e seus falsos companheiros viviam, era a festa dos negros, a congada. Rosa, instigado pela pergunta de Bizzarri: "há jeito de encontrar uma boa descrição da congada?", assim lhe responde: 
É festa que varia bastante, de lugar para lugar. Organizada pelos pretos, que a representam com sincera devoção e jubilante fanatismo. Os ranchos são independentes. Alguns denotam a origem das antigas estirpes de escravos: moçambiqueiros (Moçambique), congos (Congo). Há um rei e uma rainha na festa, brancos, em geral meninos, de boas famílias. Mas, os realmente respeitados e cridos, são um negro e uma negra: O Rei Congo e a Rainha Conga (ROSA, 2003, p. 72).

Era, pois, um acontecimento festivo da camada mais pobre e marginal do arraial, mas de muito significado social, sob a proteção dos santos negros: Nossa Senhora do Rosário; São Benedito; Santa Efigênia. O narrador do conto assim comenta: "A festa era de pretos e brancos, mas mais dos pretos: já naquele dia eles espiavam os brancos com sobrançaria de importância maior - pois eram os donos da Santa" (ROSA, p. 451). Por certo, um conto denso e significativo como o Recado do Morro - um constructo estético no limiar entre o belo natural e o belo artístico - não poderia deixar de lançar um olhar crítico e esperançoso sobre as contradições sociais que se espalhavam nos espaços rurais do sertão. $\mathrm{O}$ escritor Rosa, sem o saber, se inspirava no esteta Adorno: “...valia mais desejar que um dia melhor a arte desapareça do que ela esquecer o sofrimento, que é a sua expressão e na qual a forma tem a sua substância" (ADORNO, 2011, p. 391).

Seria o "Recado do Morro" uma "estória de formação"? Goethe, com seu livro "Os Anos de Aprendizado de Wilhelm Meister", no início do século XIX, teria dado início ao gênero literário Bildungsroman - Romance de Formação. Wilhelm Meister, filho de um exitoso comerciante burguês, não aceita trabalhar nos negócios da família e se volta inteiramente à busca de um lastro cultural, espiritual que a sua classe social, no momento, não lhe poderia fornecer. Suas aspirações formativas se manifestam na carta que escreve a seu cunhado, que o substituíra nos negócios da família. "Instruir-me a mim mesmo"; "inclinação irresistível pela formação harmônica de minha natureza"; "inclinação pela poesia e por tudo o que está relacionada com ela"; "necessidade de cultivar meu espírito e meu gosto"; ...são todas expressões da formação humanista-filosófica de um indivíduo, mas também de uma classe social em constituição, naquele momento, a burguesia. E nas 550 páginas dos oito livros que compõem Os Anos de Aprendizado, Goethe vai alinhavando o percurso do personagem na busca de sua formação, de ser ele mesmo, o mais plenamente possível (PUCCI, 2011, p. 13-42).

"Recado do Morro" é uma estória de formação; é a estória de um lavrador, que se torna guia de uma expedição por quase um mês, que convive com três personagens cultos, de características e idiossincrasias próprias: um naturalista estrangeiro, que tudo quer saber, indagar, pesquisar e que porta em suas expressões um discurso científico e, ao mesmo tempo, poético; um sacerdote também estrangeiro, mas há tempo morando no arraial mineiro, que se expressa por meio de um discurso religioso e de catequese; um negociante de bois e de gêneros agrícolas, de pouca conversa e de linguajar pragmático. Todos os personagens, no conto, "são seres em trânsito", nos lembra Lages (2004, p. 215). No longo trajeto em percurso, depara-se com pessoas estúrdias, que captaram a terrível mensagem de um 
Morro, e que vão dando a essa mensagem forma e plumagens, numa linguagem rústica e enigmática. Pedro Orósio está presente nos momentos de transmissão do recado, mas julga todas as falas "doideiras". Tem consciência de sua força física e da ajuda que pode dar aos mais fracos, aos que são ameaçados pela violência. Ainda não decidiu o seu amanhã, se volta para as terras de onde veio e tem delas saudades; "seus imaginamentos"; pensa em encontrar uma mulher, se casar, ter filhos, cultivar sua terrinha e viver em paz; mas, ao mesmo tempo, não abandona sua atitude e fama de namorador. Seu trajeto, na viagem, é de alguém que está procurando seu caminho, buscando o seu ser; mesmo sem o saber. E é o Recado do Morro, da natureza, que vai lhe mostrar os perigos iminentes que ameaçam sua existência e lhe dar garra para voltar à sua terra de origem e ser outra pessoa. "O herói é inconsciente de sua heroicidade", nos diz Bento Prado Junior (1985, p. 217). À medida, porém, que a estória da canção vai se formando, também o protagonista dessa mesma estória vai constituindo sua identidade pessoal. Como diz Ana Cristina Alves, em seu artigo "A viagem em o recado do morro: construção de espaços e identidades":

Pedro Orósio é o guia dos caminhos a percorrer no sertão, pois o fato de conhecer a geografia do lugar o coloca em evidência, mas o que marca esse texto roseano é a escolha pelo movimento de um lavrador que se transforma em guia para, no final da estória, perceber que o rei da canção era ele (ALVES, 2003, p. 26).

Ou como diz Susana Lages: "Sendo assim, ao trajeto percorrido espacialmente corresponde um percurso de aperfeiçoamento interior do protagonista: ao ser capaz de traduzir a mensagem do Morro, ele passa da condição de ignorante à de senhor do próprio destino" (2004, p. 219). É a estória de formação de um personagem viajante, que, ao contrário de Wilhelm Meister, não procurou conscientemente seu caminho, mas a vida e as circunstâncias o levaram à sua maioridade.

"A obra de arte como irrupção da objetividade na consciência subjetiva" (ADORNO, 2011, p. 368). Laudelim tinha ido no início da noite de sábado ao hotel do Sinval, "tocar e cantar" para seo Alquiste; estava presente um grande número de pessoas. "Todos batiam palmas". Pedro Orósio, acompanhado de Ivo Crônico, antes de ir ao "arrasta-pé", passara pelo hotel, para atender ao convite de seu amigo. Foi saudado, com alegria e admiração, pelo naturalista estrangeiro, que, ao vê-lo entrar no salão, sorriu para ele, levantou o copo de cerveja e o saudou efusivamente: - "Escola!...". Laudelim também tinha ficado satisfeito "de ver seu amigo cumprindo de vir, para ajudar a apreciar". Lá estava presente também o seo Jujuba. E todos ouviram, com emoção e curiosidade, a cantiga que Laudelim tinha composto, sobre o Rei e seus Guerreiros, que retratava, em forma de poesia e música, o recado do Morro, transmitido a ele pelo Coletor, na porta da Matriz.

Laudelim estava como que transtornado: "Após que pigarreou, dedeou de esbarrondo, e meteu começo, com rompante, descantou"; ... "a cantiga "era de referver". ... "Aquela estória era terrível!" O Rei traído por seus sete guerreiros; ... sangue, uivos! "tudo em estrondo e estraçalho". "Mas aí o Rei matava o derradeiro sétimo, e ele próprio morria." E todos estavam emocionados: “... se embaciavam os olhos, quase de cair lágrimas" (ROSA, p. 
455-460). E a cantiga foi apresentada novamente, para os frades ouvirem, pois frei Florduardo e frei Sinfrão chegaram depois. E Pedro Orósio, mais o Ivo, partiram para o pagode e encontraram logo adiante os outros "companheiros" que os esperavam; seguiram a estrada. "Pedro Orósio regozijava de caminhar de noite, debaixo de lua. Entremente, ia cantando. ... aquela cantiga do Rei não saía do raso de sua ideia. Canta que canta, até o Ivo também, de falsete" (IDEM, p. 462).

Destacamos o momento da estória em que a cantiga, que Pedro Orósio não parava de entoar, se transforma em revelação:

\begin{abstract}
Queria cantar: Vieram todos de parelha... o Rei ... E em eles tremeram peles ... A sina do Rei é avessa ... O Rei dava, que estrambelhava - à espada: dava de gume, cota e prancha ... "Remeteram com a fortaleza ..." Aí então os sete matavam o Rei, à traição ... Traição ... Caifaz... Parecia coisa que tinha estado escutando aquilo a vida toda! Palpitava o errado. Traição? Ah, estava entendendo. Num pingo dum instante. Olhou aqueles, em redor. Sete? Pois não eram sete?! Estarreceu, no lugar. Soprou. - Doidou, Pê? Que foi?” Traição, de morte, o dano dos cachorros! - "Pois toma, Crônhico!" - e puxou no Ivo um bofetão, com muito açoite. Estavam na ponte do Ribeirão da Onça. - "E que foi, gente? Que foi?" Ele cresceu (ROSA, 2006, p. 466).
\end{abstract}

Para Guimarães Rosa, Pedro Orósio, que estivera presente todas as vezes que o recado fora transmitido, e que, surdo e sem compreensão, não o percebeu, só consegue receber a revelação (ou a profecia, ou aviso), quando sob a forma de obra de arte. E, mais ainda, só quando ele próprio se entusiasma (em-theos = em deus) pela canção e a canta repetidamente (ROSA, 2003, p. 92-3). Enigmático é o recado do Morro, nas expressões de seus sete mensageiros, mesmo quando se transforma em uma obra de arte pelo talento e sensibilidade de seu compositor. A diferença, porém, entre as versões dos primeiros seis receptores e a versão da cantiga do Rei é o campo de forças que aquela obra de arte contém em si mesma: "Todas as obras de arte autênticas são tour de force" (ADORNO, 2011). E o protagonista Orósio só vai compreender a mensagem de vida e de morte quando a cantiga toma posse completamente de seu ser, quando ele, pleno da presença da revelação, entusiasmado (em Theós), na tensão entre o somático e o espiritual, desvenda o mistério. Adorno, no curso de Estética de 1958/59, reforça as observações de Rosa:

[...] lo que puede designarse con el nombre de entusiasmo estético no es otra cosa que la relación plenificada con la cosa misma, porque en verdad, en cuestiones de arte, no existe ningún otro entusiasmo que el estar completamente en la cosa y el extinguirse en la cosa (2013, p. 535).

Com a ajuda de Theodor Adorno, podemos entender ainda outros aspectos da metanoia, da metamorfose sofrida pelo Pê-Boi no confronto com a cantiga do Rei e seus Guerreiros. O frankfurtiano estabelece, na Teoria Estética, de 1970, uma clara distinção entre os conceitos de vivência (Erlebnis) e de experiência (Erfahrung), na interpretação de 
uma obra de arte. A vivência é um "sentimento excitado", "uma emoção subjetiva", "um momento parcial do processo e não o mais decisivo". A experiência é muito mais que isso: é fruto da entrega completa do contemplador à obra de arte; quanto mais intensa é a energia com que ele penetra no interior da mesma, tanto maior é a objetividade, o conhecimento que dela recebe. Na expressão de Adorno:

\begin{abstract}
O abalo intenso, brutalmente contraposto ao conceito usual de vivência, não é uma satisfação particular do eu, e é diferente do prazer. É antes um momento da liquidação do eu que, enquanto abalado, percebe os próprios limites e finitude. Esta experiência é contrária ao enfraquecimento do eu, que a indústria cultural promove (ADORNO, 2011, p. 369).
\end{abstract}

E há outro detalhe importante a se destacar no processo da experiência formativa de Pedro Orósio. No instante do plenilúnio do recado, quando sente na pele a atitude de traição dos sete falsos companheiros que se preparavam para matá-lo, nosso personagem-viajante é tomado de uma clarividência incisiva: a revelação da cantiga "... parecia coisa que tinha estado escutando aquilo a vida toda! Palpitava o errado. Traição? Ah, estava entendendo" (ROSA, 2006, p. 466). Pê-Boi sente nesse momento a elucidação da ambivalência que o perseguiu a viagem toda, sobretudo depois do Recado do Morro, captado por Gorgulho. O incompreensível era-lhe extremamente inquietante (Unheimlich), pois, apesar de estranho, não deixava de lhe ser familiar. Cismas, imaginamentos, momentos de desconfianças, sobretudo no contato com Ivo e seus comparsas, se escondem em diversos lugares e momentos na estória. "O estranho ... não nos é indiferente; é-nos inquietantemente estranho e familiar a um só tempo" (CACHOPO, 2013, p. 262). Ou como nos manifesta Adorno, na Teoria Estética:

O que parece a todos compreensível é o que se tornou incompreensível; o que os manipulados afastam de si é-lhes simplesmente, secretamente, demasiado compreensível; isto por analogia com a afirmação de Freud segundo a qual o estranhamente inquietante é inquietante (Unheimlich), como o que secretamente é demasiado familiar. É por isso que é repelido (2011, p. 278).

Agora tudo parece evidente para Pedro Orósio: “... estava entendendo”. Era hora de assumir-se a si mesmo, de realizar o que sempre o inquietava e, ao mesmo tempo, o atraia. A experiência da arte, enquanto a irrupção, em sua consciência, da objetividade dos fatos anunciados pelo recado do Morro, enquanto explosão de algo vivo que vem de dentro da obra, atinge com intensidade seu contemplador e lhe propicia o contato íntimo como o conteúdo de verdade que ela carrega em suas entranhas, transforma-se nele em força viva e em exuberância. Avança sobre seus inimigos “...Toma cão!”. ... E, depois de vencê-los e desbaratá-los, se manda para onde há muito tempo desejava regressar; agora, porém, não apenas como um simples homem do campo, um enxadeiro; e sim, do mesmo modo, como um guia, como alguém que atingiu sua maioridade, como alguém pronto para iniciar outro estágio em sua vida; como alguém que aprendeu uma importante lição: construir sua 
família na continuidade do sonho de Adão. "Daí, com medo de crime, esquipou, mesmo com a noite, abriu grandes pernas. Mediu o mundo. Por tantas serras, pulando de estrela em estrela, até aos seus Gerais" (ROSA, 2006, p. 467).

\section{CONSIDERAÇõES FINAIS}

"Quanto mais o contemplador se entrega tanto maior é a energia com que penetra na obra de arte e a objetividade que ele percebe no interior" (ADORNO, 2011, p. 266). Nosso propósito, neste ensaio, foi interpretar o conto "O Recado do Morro" em diálogo com as reflexões estético-filosóficas de Theodor Adorno. E tentamos desenvolver nosso empreendimento destacando cinco eixos teórico-metodológicos não presentes nas obras dos autores tidos por nós como os principais intérpretes do referido conto:

- a tensão entre a mimese e a racionalidade, entre o reino da natureza, da sensibilidade e as dimensões do construtivo e das técnicas;

- a constelação como procedimento metodológico de Rosa na caracterização/constituição de seus personagens; nos detivemos em dois deles;

- A obra de arte como crítica da sociedade de onde ela proveio;

- O Recado do Morro como uma "estória de formação" de seu protagonista;

- A obra de arte como irrupção da objetividade na consciência subjetiva de Pedro Orósio.

Certamente, outros eixos poderiam ser destacados e desenvolvidos na contemplação imanente dessa obra de arte.

Pedro Orósio, enquanto seguia caminhando com seus falsos companheiros em direção à festa, em noite de lua cheia, tocado profundamente pela cantiga de Laudelim, lembrava-se dos valores humanos e morais apregoados pelo sábio seu Alquiste: Kalós kai Agathós: belo e bom. "Gostava daquela música. Gostava de viver" (ROSA, 2006, p. 462). Ele tinha ido até os campos-gerais, com a caravana, e lá devia ter ficado, colhendo em sua roça - era o que "de profundis" lhe dizia a cantiga do Rei e seus Guerreiros, encantada por Laudelim. E um último "imaginamento", que lhe fazia bem, lhe vem à mente, pouco antes de perceber a traição:

\footnotetext{
Um homem chega à porta de sua casa, se rindo de si e escorrendo água, desvestia pesada a croça de fibra de palmeira boa. E uma mulher moça, dentro de casa, se rindo para o homem, dando a ele chá de folha do campo e creme de cocos bravos. E um menino, se rindo para a mãe na alegria de tudo, como quando tudo era falante, no inteiro dos campos-gerais (ROSA, 2006, p. 463).
}

Talvez esse "imaginamento" final, fruto da cantiga e da vontade de viver, lhe tenha fortemente ajudado a captar a mensagem e dado início a seu intento de uma nova vida. 


\section{REFERÊNCIAS}

ADORNO, T. W. A arte é alegre? In: RAMOS-DE-OLIVEIRA, N. et alii. Teoria Crítica, Estética e Educação. Campinas: Autores Associados/Piracicaba: Editora da UNIMEP, 2001, p. 11-18.

. Dialética Negativa. Trad. de Marco Antonio Casanova. São Paulo: EDUNESP, 2009.

. Teoria Estética, 2. ed. Tradução de Artur Morão. Lisboa: Edições 70, 2011.

ALVES, A. C. T. A viagem em o recado do morro: construção de espaços e identidades. Revista Estação Literária. Londrina, v. 10B, p. 20-32, jan. 2013.

CACHOPO, J. P. Verdade e Enigma: Ensaio sobre o pensamento estético de Adorno. Lisboa: Edições Vendaval, 2013.

HOUAISS, A. Dicionário Houais da Língua Portuguesa. Rio de Janeiro: Editora Objetiva, 2001.

JAEGER, W. Paidéia: A Formação do Homem Grego, 4. ed. Tradução de Artur M. Parreira. São Paulo: Martins Fontes, 2001.

LAGES, S. K. Descaminhos da leitura como escrita e tradução: uma interpretação de "O recado do morro", de João Guimarães Rosa. Cadernos de Tradução. Florianópolis, Brasil, 2004, p. 212-222.

MACHADO, A. M. Em Nome do Homem. In: Recado do Nome: leitura de Guimarães Rosa à luz do Nome de seus personagens, 3. ed. Rio de Janeiro: Nova Fronteira, 2003.

MARTINS, N. S. O Léxico de Guimarães Rosa. São Paulo: Edusp/Fapesp, 2001.

PERIUS, O. A filosofia da linguagem em Walter Benjamin. Semana Acadêmica do PPG em Filosofia da PUCRS. VII Edição, 2011, p. 96-105. Disponível em: $<$ http://ebooks. pucrs.br/edipucrs/anais/semanadefilosofia/edicao7/Oneide Perius.pdf $>$. Acesso em $16 \mathrm{de}$ mar. 2017.

PRADO JUNIOR, B. O Destino Decifrado - Linguagem e Existência em Guimarães Rosa. Alguns Ensaios: Filosofia, Literatura, Psicanálise. São Paulo: Paz e Terra, 2. ed. 2000.

PUCCI, B. Para Rosa com Adorno: a luta agônica da palavra e do conceito em busca do "quem" das coisas. Revista Artefilosofia, UFOP, v. 8, p. 122-133, 2010.

. Os Anos de Aprendizado de Wilhelm Meister e a questão da Bildung em Theodor Adorno. In: VERLANG, Júlio César; ROSIN, Nilva (Orgs.). Theodor Adorno: diálogos filosóficos em educação, ética e estética. Passo Fundo: Editora IFIBE, 2011, p. 13-42. 
. A Dialética negativa enquanto metodologia de pesquisa em educação: atualidades. Revista e-Curriculum (PUCSP), v. 8, p. 1-24, 2012.

PUCCI, Bruno; AQUINO, L. C. A.; ROMEIRO, A. E. A Obra de Arte como Práxis. Revista Artefilosofia, UFOP, 2015, v. 19, p. 1-12.

REINALDO, G. Uma cantiga de se fechar os olhos ... Mito e Música em Guimarães Rosa. São Paulo: Annablume; FAPESP, 2005.

ROSA, J. G. Correspondência com seu tradutor italiano Edoardo Bizzarri, 3. ed. Rio de Janeiro: Nova Fronteira, 2003.

. Carta de Guimarães Rosa dirigida ao Padre João Batista Boaventura Leite, em 26 de agosto de 1963. Disponível em: $<\mathrm{http}$ ://orecadodomorrodeguimaraesrosa. blogspot.com.br/2008/08/carta.html>. Acesso em 14 de mar. 2017.

. Recado do Morro. In: Corpo de Baile: edição comemorativa 50 Anos (19562006), Rio de Janeiro: Editora Nova Fronteira, v. 2, p. 389-467, 2006.

WISNIK, J. M. O recado do morro [João Guimarães Rosa] (vídeo). Disponível em: $<$ https://www.youtube.com/watch?v=BE64BrBt52E>. Acesso em 14 de mar. 2017.

\section{Dados dos AUtORES:}

\section{Bruno Pucci}

Doutor em Educação: História, Política, Sociedade pela Pontifícia Universidade Católica de São Paulo. Professor na Universidade Metodista de Piracicaba. Piracicaba/SP - Brasil. puccibru@gmail.com

\section{Gloria Bonilha Cavaggioni}

Mestre em Educação pela Universidade Metodista de Piracicaba. Atua principalmente nos temas: cultura popular tradicional e cultura caipira. Piracicaba/SP - Brasil. gloriacavaggioni@gmail.com

\section{Luis Fernando Altenfelder de Arruda Campos}

Doutorando em Educação Escolar na Universidade Estadual Paulista "Júlio de Mesquita Filho", campus Araraquara. Psicólogo Educacional do Instituto Federal de Educação Ciência e Tecnologia, campus Piracicaba. Piracicaba/SP - Brasil. lualarruda@hotmail.com

Submetido em: 16-5-2018

Aceito em: 15-3-2019 